\title{
HUBUNGAN ANTARA KETERLIBATAN AYAH DENGAN PEMBENTUKAN KARAKTER PADA REMAJA
}

\author{
Widya Lestari ${ }^{1)}$, Sitti Nursetiawati ${ }^{2)}$, Vera Utami GP $^{3)}$ \\ ${ }^{1,2,3)}$ Program Studi Pendidikan Kesejahteraan Keluarga \\ Fakultas Teknik, Universitas Negeri Jakata
}

\begin{abstract}
Abstrak
Penelitian itu bertujuan untuk mencari hubungan antara keterlibatan ayah dengan pembentukan karakter pada remaja. Penelitian dilakukan di SMP Negeri 2 kota Bogor. Penelitian ini merupakan penelitian kuantitatif dengan teknik sampling cluster random sampling. Sampel penelitian ini bejumlah 169 remaja. Pengumpulan data dilakukan dengan menggunakan angket yang dikembangkan berdasarkan Teori Fox and Bruce (2001) dan Kemendikbud (2011). Hasil penelitian menunjukan adanya hubungan yang signifikan dan searah antara keterlibatan ayah dengan karakter anak dengan indeks korelasi sebesar 0.442 .
\end{abstract}

Kata kunci: keterlibatan ayah, karakter, pembentukan karakter.

\section{CORRELATION BETWEEN FATHER INVOLVEMENT WITH FORMATION OF ADOLESCENT CHARACTER}

\begin{abstract}
The research is aimed to find relationship between the father involvement with the formation of character in adolescents The research was conducted in Junior High School 2 Bogor City. Quantitative research methods was used in this research with cluster of random sampling. There are 169 respondent as a sample. The questionnaire was developed based on Fox and Bruce Theory (2001) dan Ministry of Education (2011). Reserch found that there are a significant correlation between the father involvement with the character behaviour of a adolescents ( 0.442 correlation coefficient)
\end{abstract}

Keywords: father involvement, formation of character.

\section{PENDAHULUAN}

Usia remaja dipandang sebagai periode kritis atau waspada. Di usia ini mereka tertarik untuk belajar menduplikasi dan mencoba hal-hal baru. Baik hal positif ataupun negatif. Rata-rata, remaja mengalami metamorfosis yang tidak jelas, sehingga sikap diri mereka cenderung labil dan berubah-ubah. Kelabilan yang terjadi pada diri mereka harus diperhatikan dengan baik karena nantinya akan berpengaruh pada karakter diri remaja itu sendiri.

Menurut Harian Kompas 6 Desember 2012, berdasarkan indeks persepsi korupsi, yang dilaksanakan oleh lembaga Survei Transparancy International, Indonesia masih masuk jajaran negara-negara terkorup dengan menempati peringkat ke-118 dari 174 negara (Kompas, 2012). Di harian yang sama, Badan Kehormatan DPR melaporkan ada 28 anggota dewan tersangkut masalah etika.
Dari dua fenomena di atas, negeri ini berada dalam krisis multidimensional yang tak kunjung usai. Kondisi diperburuk dengan krisis moral dan budi pekerti para pemimpin bangsa yang berimbas kepada generasi muda. Tawuran antar pelajar, perilaku seks bebas, penyalahgunaan narkoba, budaya tak tahu malu, tata nilai dan norma yang semakin merosot tidak hanya di perkotaan tapi sudah merambah ke pedesaan (Zuriah, 2007).

Sebagai alternatif yang bersifat preventif, pendidikan diharapkan dapat mengembangkan kualitas generasi muda bangsa dalam berbagai aspek yang dapat memperkecil dan mengurangi penyebab berbagai masalah budaya dan karakter bangsa. Untuk mengatasi kondisi tersebut diperlukan pemahaman dan langkah untuk membangun kembali karakter bangsa sesuai nilai-nilai Pancasila. Sekolah yang diharapkan mampu membantu proses pembentukan karakter remaja, tidak mungkin bisa mencapai tujuannya jika tidak ada bantuan 
dari keluarga yang seharusnya menjadi tempat pertama bagi remaja untuk belajar dan membentuk karakter diri.

Karakter merupakan aspek penting untuk peningkatan kualitas sumber daya masyarakat karena kualitas karakter bangsa menentukan kemajuan suatu bangsa. Untuk itu karakter yang berkualitas perlu dibentuk dan dibina sejak usia dini. Pendidikan karakter dinilai berhasil apabila anak telah menunjukkan kebiasaan berperilaku baik dan dapat memaknai serta menghargai nilai karakter tersebut. Untuk itu pembentukan karakter anak harus berkaitan dengan aspek kognitif dan dikuatkan dengan aspek afektif.

Implementasi aspek ini dalam pendidikan formal di Indonesia dengan mewajibkan siswa sampai mahasiswa menempuh mata pelajaran/mata kuliah pendidikan agama dan Pendidikan Pancasila karena mata pelajaran ini berisi tentang pengembangan moral dan karakter anak. Namun pada kenyataannya masih banyak permasalahan karakter yang terjadi pada diri remaja. Aksi bullying, mencontek massal, seks bebas, tawuran, dan berbagai bentuk pelanggaran karakter lainnya. Bahkan, sudah tidak ada lagi rasa malu bagi remaja saat melakukan pelanggaran norma dan etika di depan umum. Contohnya di depan guru, mereka tidak ragu lagi mempertunjukan kemesraan yang bukan dalam lingkup usianya.

Data Sensus Nasional dan Kementerian Agama Kota Bogor menyebutkan tingkat kehamilan dan pernikahan usia remaja di tahun 2013 semakin meningkat. Tercatat, 1.626 pasangan menikah di usia yang masih sangat dini, dan terdapat 90 pasangan yang mengajukan dispensasi usia pernikahan di pengadilan agama kota Bogor kelas 1B (Kabar Bogor, 15-08-2014).

Hasil survey ini di dukung juga dengan hasil dari Badan Pusat Statistik (BPS) yang mencatat dari 5.465 responden, sebanyak $87 \%$ mengaku sudah tidak perawan, bahkan 56\%nya mengaku sudah pernah melakukan aborsi. Seperti yang diberitakan di harian Merdeka (8 Mei 2014), berdasarkan razia yang dilakukan oleh satgas pelajar kota Bogor, dari 40 anak yang terjaring razia, 10 di antaranya ditangkap karena terbukti sering membawa senjata tajam dan mengumpulkan video porno di dalam handphone-nya. Beberapa kebiasaan ini yang pada akhirnya membuat karakter mereka menjadi remaja tanpa toleransi dan kehilangan etika.
Berdasarkan catatan dari Komnas HAM, kasus tawuran di Indonesia pada 2011 tercatat 339 kasus dimana 82 orang pelajar meninggal dunia akibat tawuran (Lodaya Post, 08-032012). Satuan Petugas pengawasan pelajar kota Bogor juga mendata, dari tahun 2011 hingga tahun 2014, khusus di kota Bogor 28 orang menjadi korban tewas dalam aksi tawuran pelajar, dan jumlah korban ini akan terus meningkat setiap tahunnya, karena aksi tawuran pada tahun 2011 sampai 2012 saja meningkat pesat hingga 128 kasus (Satgas Pelajar Bogor, dalam Lodaya Post, 08-03-2012).

SMP Negeri 2 Bogor merupakan salah satu SMP Favorit di kota Bogor. Hal ini dapat kita lihat dari passing grade-nya yang tiap tahun meningkat dalam data yang dimiliki oleh Dinas Pendidikan dan Kebudayaan Kota Bogor. Tetapi meningkatnya passing grade tidak disikapi dengan meningkatnya karakter diri tiap siswa-nya.

Berdasarkan wawancara yang dilakukan oleh peneliti dan studi pendahuluan pada 10 orang anak, menunjukan ada beberapa gejala kerusakan karakter yang terjadi di SMP Negeri 2 Bogor yang berkaitan dengan keterlibatan orang tua dalam pengasuhan di rumah. Wawancara dan studi pendahuluan yang dilakukan peneliti sepanjang bulan September 2014 menunjukan banyak siswa yang sudah kehilangan nilai sopan santun terhadap guru dan orang yang lebih tua di sekitar lingkungan sekolah. Selain nilai sopan santun, terdapat nilai lain yang ikut terkikis dalam diri remaja di SMP Negeri 2 Bogor, seperti nilai toleransi, nilai kedisiplinan, nilai kasih sayang, nilai agama dan nilai moral.

$\begin{aligned} \begin{array}{r}\text { Salah satu faktor penting yang } \\ \text { mendukung keberhasilan remaja dalam }\end{array} & \text {. }\end{aligned}$ menyelesaikan permasalahannya adalah keluarga. Bronfenbrenner (dalam Santrock, 2002) menyatakan bahwa dalam mikrosistem terjadi interaksi langsung dengan agen-agen sosial, yang sangat berpengaruh bagi individu. Sebagai unit sosial terkecil, terdapat hubungan timbal balik dalam keluarga. Keluarga yang menentukan akan menjadi apa generasi penerus yang mereka lahirkan.

Generasi yang kuat, kreatif dan solutif adalah harapan setiap masyarakat dapat dibentuk dengan memaksimalkan lapisan inti yaitu keluarga melalui parenting yang baik. Keterlibatan ayah dan ibu adalah sarana untuk membentuk sikap, tingkah laku, watak, kepribadian, karakter, dan moral seorang anak. Ayah dan ibu memiliki peran utama dalam penanaman nilai-nilai dasar kehidupan. 
Keterlibatan ayah termasuk keterlibatan positif yang dimiliki ayah dengan anaknya (Pleck dalam Hodgins, 2007). Menurut Vera dan Putri (dalam Abdullah, tanpa tahun) peran ibu terkait merawat (caretaking) dan memberi kasih sayang (nurturance) lebih berhubungan dengan pengasuhan dan perawatan fisik. Sementara ayah, erat dengan interaksi bermain dan menjelajah, ayah berkaitan dengan segi rasional anak sementara ibu berkaitan dengan emosional.

Dalam beberapa penelitian, telah dibuktikan bahwa keterlibatan ayah dalam pengasuhan anak sangat penting manfaatnya bagi anak, khususnya dalam hal kognitif, emosi, dan sosial. Manfaat- manfaat tersebut dirasakan oleh anak bahkan hingga dewasa atau remaja (Allen dan Daly, 2002). Selain itu, disebutkan pula bahwa keterlibatan ayah yang baik dapat mengurangi kemungkinan anak melakukan externalizing behavior (Erawati, 2009).

Permasalahan yang kemudian muncul adalah adanya asumsi bahwa peran ibu yang paling menentukan keberhasilan remaja dan pandangan bahwa tugas utama ayah hanya mencari nafkah. Hal ini bisa menyebabkan ketidakoptimalan dalam pembentukan karakter anak. Terlebih ditengah kompetisi industri yang semakin tinggi sehingga banyak ayah yang minim interaksi dengan anak, sedangkan pesatnya informasi dan pergaulan bebas yang semakin membudaya dapat mengancam nilainilai remaja serta menggerus karakternya. Ancaman ke-tidakoptimalan parenting kini semakin tinggi. Sebab, tidak sedikit ayah dan anak remaja yang berjauhan karena tuntutan pekerjaan ayah atau kurangnya interaksi. Bahkan kadang beberapa ayah hanya merasa memiliki kewajiban memberi uang jajan, dan selebihnya itu tugas ibu untuk mampu membentuk generasi yang berkarakter, kuat, kreatif dan solutif.

Berdasarkan latar belakang dan permasalahan tersebut, penulis melakukan penelitian dengan memfokuskan pada hubungan keterlibatan ayah dan pembentukan karakter pada remaja.

\section{Keterlibatan Ayah}

Dalam Kamus Besar Bahasa Indonesia (KBBI, 2005), "ayah" adalah orang tua laki-laki seorang anak. Dalam hubungannya dengan sang anak, seorang "ayah" bisa merupakan anak kandung (ayah secara biologis) atau ayah angkat. Ayah merupakan gelar yang diberikan kepada seorang pria apabila pria itu sudah memiliki anak terlepas anak itu anak kandung ataupun anak angkat. Dalam hubungan kekerabatan kata ayah memiliki pengertian sebagai seorang kepala keluarga yang diharapkan membawa kesejahteraan bagi keluarganya (Tambunan, 2010).

Fathering merupakan peran yang dimainkan seseorang yang berkaitan dengan anak, bagian dari sistem keluarga, komunitas, dan budaya Lynn (dalam Frogman, 2002). Menurut Cabrerra (2001), keterlibatan ayah adalah konsep multidimensi yang terus berkembang baik dalam segi pengetahuan maupun kesadaran publik. Sementara Hawkins (dalam Lamb, 1997) mendefinisikan keterlibatan ayah sebagai sebuah konstruksi multidimensi yang mencakup komponen afektif, kognitif, dan etis, serta komponen tingkah laku yang dapat diobservasi, termasuk juga di dalamnya bentuk keterlibatan secara tidak langsung, seperti mendukung peran ibu dalam pengasuhan dan penyediaan penghidupan bagi keluarga. Keterlibatan ayah adalah perilaku ikut serta secara positif yang dilakukan ayah dalam pengasuhan anaknya (Pleck dalam Hodgins, 2007).

Keterlibatan dalam pengasuhan diartikan sebagai seberapa besar usaha yang dilakukan oleh seorang ayah dalam berpikir, merencanakan, merasakan, memperhatikan, memantau, mengevaluasi, mengkhawatirkan serta berdoa bagi anaknya (Palkovits, 2002). Melihat dari perspektif anak, keterlibatan ayah diasosiasikan dengan ketersediaan kesempatan bagi anak untuk melakukan sesuatu, kepedulian, dukungan dan rasa aman. Anak yang ayahnya terlibat dalam pengasuhan dirinya akan memiliki kemampuan sosial dan kognitif yang baik, serta kepercayaan diri yang tinggi (Palkovits, 2002). Hal ini terjadi bila ayah mengembangkan model pengasuhan yang positif. Keterlibatan akan menimbulkan efek yang negatif apabila dalam praktek pengasuhannya, ayah menunjukkan perilaku negatif, dan melibatkan hukuman fisik.

Fathering merefleksikan keterlibatan positif ayah dalam pengasuhan melalui aspek afektif, kognitif, dan perilaku. Ayah bertanggung jawab secara primer terhadap kebutuhan finansial keluarga. lbu bertanggung jawab terhadap pengasuhan dasar, seperti bermain dengan anak, dukungan emosional, monitoring, dan hal yang berkaitan dengan disiplin dan aturan yang cenderung dibagi bersama oleh ayah dan ibu (Erwawati, 2009). 
Keterlibatan ayah seringkali digambarkan dengan jumlah waktu yang ayah habiskan bersama dengan anaknya atau interaksi langsung antara ayah dan anak (Hawkins, dkk, 2002). Hal itu terjadi karena waktu seringkali dianggap orang tua sebagai hal yang paling penting dalam keterlibatan dengan anak (Daly \& Hochschild dalam Hawkins, dkk, 2002). Akan tetapi, waktu bukanlah satu-satunya dimensi yang penting dalam keterlibatan ayah (Palkovitz dalam Hawkins, dkk, 2002).

Keterlibatan ayah dalam pola asuh memberi dampak positif pada anak. la memberikan warna tersendiri dalam pembentukan karakter anak. Ikatan ayah anak juga mampu meningkatkan kemampuan adaptasi anak, anak menjadi tidak mudah stres atau frustrasi sehingga lebih berani mencoba hal-hal yang ada di sekelilingnya. Dan dari penjabaran di atas dapat disimpulkan bahwa keterlibatan ayah adalah perilaku ikut serta ayah dalam pengasuhan anak mencakup aspek kognitif, afektif, dan tingkah laku.

\section{Dimensi Keterlibatan Ayah}

Menurut Erawati (dalam Fox \& Bruce, 2001) mengemukakan konsep fathering yang sangat kental dengan perspektif Parental Investment Theory (PIT). Dimensi-dimensi keterlibatan ayah diukur dengan :

1. Responsivity: kuantitas ayah menggunakan kehangatan, kasih sayang, dan sikap suportif. Komponen ini mencakup pemahaman ayah untuk memenuhi kebutuhan anak, termasuk menyediakan sumber keuangan untuk anak, dan merencanakan serta mengelola kehidupan anak. Dalam dimensi ini, ayah juga diminta untuk berinteraksi langsung dengan anak, baik secara pikiran, perhatian, dan perencanaan yang dilakukan untuk anak

2. Harshness: kuantitas ayah menggunakan sikap galak, menghukum, dan pendekatan inkonsisten. Komponen ini mecakup sikap ayah dalam mengaplikasikan ketegasannya kehadiran ayah dan ketersediaan ayah untuk anak.

3. Behavioral engagement: kuantitas ayah terlibat aktivitas dengan anak. Komponen ini mencakup pengalaman ayah dalam melakukan kontak langsung dan interaksi bersama dengan anak dalam bentuk pengasuhan, bermain, atau mengisi waktu luang.

4. Affective Involvement: Kuantitas ayah menginginkan dan menyayangi anak. Komponen ini mempresentasikan waktu yang dihabiskan dalam interaksi langsung ayah dengan anak dan tidak mencakup waktu yang dihabiskan dalam kedekatan ayah dan anak, sebagai bentuk pengakuan dari ayah terhadap kehadiran anaknya.

\section{Karakter}

Menurut Saunders (1977) karakter adalah sifat nyata dan berbeda yang ditunjukkan oleh individu, sejumlah atribut yang dapat diamati pada individu. Dijelaskan bahwa ada perbedaan karakter individu dengan individu lainnya. Menurut Saunders perbedaan karakter tersebut dapat dilihat atau diamati karena memang karakter itu ada kaitannya dengan perilaku hidup setiap hari yang ditampilkan oleh setiap individu.

Selanjutnya, Gulo (1982) mendefinisikan bahwa karakter adalah kepribadian ditinjau dari titik tolak etis atau moral, misalnya kejujuran seseorang, biasanya mempunyai kaitan dengan sifat-sifat yang relatif tetap. Karakter juga dihubungkan dengan standard etis-moral seseorang. Nilai etis-moral tersebut terlihat dalam sikap jujur seseorang atau individu yang bersangkutan. Artinya, karakter terlihat dalam tataran aplikasi perilaku hidup setiap hari.

Kamisa (1997) menegaskan bahwa karakter adalah sifat-sifat kejiwaan, akhlak atau budi pekerti yang membedakan seseorang dari yang lain, tabiat, watak. Berkarakter artinya mempunyai watak, mempunyai kepribadian. Istilah karakter bersumber dari bahasa Yunani "karasso" yang berarti "to mark" yaitu menandai atau mengukir, yang memfokuskan bagaimana mengaplikasikan nilai kebaikan dalam bentuk tindakan atau tingkah laku. Oleh sebab itu seseorang yang berperilaku tidak jujur, kejam atau rakus dikatakan sebagai orang yang berkarakter jelek, sementara orang yang berperilaku jujur, suka menolong dikatakan sebagai orang yang berkarakter mulia. Jadi istilah karakter erat kaitannya dengan personality (kepribadian) seseorang (Wyne, 2001)

Kemudian, Alwisol menjelaskan pengertian karakter sebagai penggambaran tingkah laku dengan menonjolkan nilai (benar-salah, baik-buruk) baik secara eksplisit maupun implisit. Karakter berbeda dengan kepribadian kerena pengertian kepribadian dibebaskan dari 
nilai. Meskipun demikian, baik kepribadian (personality) maupun karakter berwujud tingkah laku yang ditujukan ke lingkungan sosial, keduanya relatif permanen serta menuntun, mengerahkan dan mengorganisasikan aktifitas individu.

Secara umum istilah "karakter" sering disamakan dengan istilah "temperamen", "tabiat", "watak" atau "akhlak" dengan definisi yang menekankan pada unsur psikososial yang dikaitkan dengan pendidikan dan konteks lingkungan. Menurut bahasa, karakter memiliki berbagai arti seperti: "character" (latin) yang berarti berarti instrument of marking; "charessein" (Perancis) berarti to engrove (mengukir); "watek" (Jawa) berarti ciri wanci; "watak" (Indonesia) berarti sifat pembawaan yang mempengaruhi tingkah laku, budi pekerti, tabiat, dan peringai.

Dalam kamus besar Bahasa Indonesia (KBBI,1995), istilah "karakter" berarti sifat-sifat kejiwaan, akhlak atau budi pekerti yang membedakan seseorang dari yang lain: tabiat, watak. Karakter yang baik menurut Maxwell (2001) lebih dari sekedar perkataan, melainkan sebuah pilihan yang membawa kesuksesan. la bukan anugerah, melainkan dibangun sedikit demi sedikit, dengan pikiran, perkataan, perbuatan, kebiasaan, keberanian usaha keras, dan bahkan dibentuk dari kesulitan hidup.

Dalam National Conference on Character Bulding di Jakarta (2005), karakter didefinisikan sebagai berikut:

"Character has been defined as the inner disposition conductive to right conduct. It is a person's collection of attitudes and habits which enable and facilitate moral action. It is the foundation for all activity in the world; every task and every achievement bears the imprint of ones's character. Moreover, as we shall see, one result of attaining good character is that individuals are able to love others well and become more productive citizens. Good character is thus the foundation for all human endeavors".

Pendidikan karakter telah menjadi perhatian berbagai negara dalam rangka mempersiapkan generasi yang berkualitas, bukan hanya untuk kepentingan individu warga negara, tetapi juga untuk warga masyarakat secara keseluruhan. Pendidikan karakter dapat diartikan sebagai usaha secara sengaja dari seluruh dimensi kehidupan sosial untuk membantu pembentukan karakter secara optimal (Lickona, 2012).
Pendidikan karakter menurut Lickona (2012) mengandung tiga unsur pokok, yaitu mengetahui kebaikan (knowing the good), mencintai kebaikan (desiring the good), dan melakukan kebaikan (doing the good). Pendidikan karakter tidak sekedar mengajarkan mana yang benar dan mana yang salah kepada anak, tetapi lebih dari itu pendidikan karakter menanamkan kebiasaan (habituation) tentang yang baik sehingga peserta didik paham, mampu merasakan, dan mau melakukan yang baik. Pendidikan karakter ini membawa misi yang sama dengan pendidikan akhlak atau pendidikan moral. Menurut Lickona (2012), karakter mulia (good character) meliputi pengetahuan tentang kebaikan, lalu menimbulkan komitmen (niat) terhadap kebaikan, dan akhirnya benar-benar melakukan kebaikan.

Dengan kata lain, karakter mengacu kepada serangkaian pengetahuan (cognitives), sikap (attitides), dan motivasi (motivations), serta perilaku (behaviors) dan keterampilan (skills). Karakter berkaitan dengan konsep moral (moral knonwing), sikap moral (moral felling), dan perilaku moral (moral behavior). Berdasarkan ketiga komponen ini dapat dinyatakan bahwa karakter yang baik didukung oleh pengetahuan tentang kebaikan, keinginan untuk berbuat baik, dan melakukan perbuatan kebaikan. Pendidikan karakter adalah usaha sengaja (sadar) untuk membantu manusia memahami, peduli tentang, dan melaksanakan nilai-nilai etika inti (Lickona,2012).

Pendidikan karakter adalah usaha yang sungguh-sungguh untuk memahami, membentuk, memupuk nilai-nilai etika, baik untuk diri sendiri maupun untuk semua warga masyarakat atau warga negara secara keseluruhan (Kemendikbud, 2011). Dalam pendidikan karakter terdapat tujuh unsur-unsur karakter esensial dan utama yang harus ditanamkan kepada peserta didik yang meliputi:

1. Ketulusan hati atau kejujuran (honesty).

2. Belas kasih (compassion);

3. Kegagahberanian (courage);

4. Kasih sayang (kindness);

5. Kontrol diri (self-control);

6. Kerja sama (cooperation); dan

7. Kerja keras (deligence or hard work).

Dalam naskah akademik Pengembangan Pendidikan Budaya dan Karakter Bangsa, Kemendikbud telah merumuskan 18 nilai karakter yang akan dikembangkan atau ditanamkan kepada anak-anak dan generasi muda bangsa Indonesia (Kemendikbud, 2011). 
Nilai-nilai karakter tersebut dideskripsikan sebagai berikut:

1. Religius. Sikap dan perilaku yang patuh dalam melaksanakan ajaran agama yang dianutnya, toleran terhadap pelaksanaan ibadah agama lain, dan hidup rukun dengan pemeluk agama lain.

2. Jujur. Perilaku yang dilaksanakan pada upaya menjadikan dirinya sebagai orang yang selalu dapat dipercaya dalam perkataan, tindakan, dan pekerjaan.

3. Toleransi. Sikap dan tindakan yang menghargai perbedaan agama, suku, etnis, pendapat, sikap, dan tindakan orang lain yang berbeda dari dirinya.

4. Disiplin. Tindakan yang menunjukkan perilaku tertib dan patuh pada berbagai ketentuan dan peraturan.

5. Kerja keras. Perilaku yang menunjukkan upaya sungguh- sungguh dalam mengatasi berbagai hambatan belajar dan tugas, serta menyelesaikan tugas dengan sebaikbaiknya.

6. Kreatif. Berpikir melakukan sesuatu untuk menghasilkan cara atau hasil baru dari sesuatu yang telah dimiliki.

7. Mandiri. Sikap dan perilaku yang tidak mudah tergantung pada orang lain dalam menyelesaikan tugas-tugas.

8. Demokratis. Cara berpikir, bersikap, dan bertindak yang menilai sama hak dan kewajiban dirinya dan orang lain.

9. Rasa ingin tahu. Sikap dan tindakan yang selalu berupaya untuk mengetahui lebih mendalam dan meluas dari sesuatu yang dipelajarinya, dilihat, dan didengar

10.Semangat kebangsaan. Cara berpikir, bertindak, dan berwawasan yang menempatkan kepentingan bangsa dan negara di atas kepentingan diri dan kelompoknya.

11. Cinta tanah air. Cara berpikir, bersikap, dan berbuat yang menunjukkan kesetiaan, kepedulian, dan penghargaan yang tinggi terhadap bahasa, lingkungan fisik, sosial, budaya, ekonomi, dan politik bangsa.

12. Menghargai prestasi. Sikap dan tindakan yang mendorong dirinya untuk menghasilkan sesuai yang berguna bagi masyarakat, dan mengakui, serta menghormati keberhasilan orang lain.

13.Bersahabat / komunikatif. Tindakan yang memperhatikan rasa senang berbicara, bergaul, dan bekerja sama dengan orang lain.

14. Cinta damai. Sikap, perkataan, dan tindakan yang menyebabkan orang lain merasa senang dan aman atas kehadiran dirinya.

Jurnal Kesejahteraan Keluarga dan Pendidikan, Vol. 4 No.1, April 2015
15.Gemar membaca. Kebiasaan menyediakan waktu untuk membaca berbagai bacaan yang memberikan kebajikan bagi dirinya.

16.Peduli lingkungan. Sikap dan tindakan yang selalu berupaya mencegah kerusakan pada lingkungan alam di sekitarnya, dan mengembangkan upaya-upaya untuk memperbaiki kerusakan alam yang sudah terjadi.

17.Peduli sosial. Sikap dan tindakan yang selalu ingin memberi bantuan pada orang lain dan masyarakat yang membutuhkan.

18.Tanggung jawab. Sikap dan perilaku seseorang untuk melaksanakan tugas dan kewajibannya, yang seharusnya dia lakukan, terhadap diri sendiri, masyarakat, lingkungan (alam, sosial dan budaya), negara dan Tuhan Yang Maha Esa.

Dalam Desain Induk Pendidikan Karakter, Kemendikbud juga telah menjelaskan konfigurasi karakter dalam konteks proses psikososial dan sosial-kultural dalam empat kelompok besar, yaitu:

1. Olah hati (spiritual and emotional development);

2. Olah pikir (intellectual development);

3. Olahraga dan kinestetik (physical and kinesthetic development); dan

4. Olah rasa dan karsa (affective and creativity development).

\section{METODE PENELITIAN}

Penelitian ini dilakukan pada 169 sampel dari kelas VII di SMP Negeri 2 Bogor. Teknik pengambilan sampel menggunakan metode probability sampling dengan teknik pengumpulan data jenis cluster sampling. Instrumen penelitian adalah kuesioner dengan variabel keterlibatan ayah (diadaptasi dari Fox and Bruce, 2001) dan pembentukan Karakter (diadaptasi dari Kemendikbud, 2011). Kedua instrumen ini menggunakan item dengan skala Likert.

\section{HASIL DAN PEMBAHASAN}

Hubungan antara keterlibatan ayah dengan pembentukan karakter pada remaja diketahui melalui uji korelasi antara skor keterlibatan ayah dengan skor karakter anak, dan teknik korelasi Pearson Product Moment (PPM). Berdasarkan hasil perhitungan korelasi antara keterlibatan ayah dengan karakter anak didapatkan koefisien korelasi $\left(r_{x y}\right)$ sebesar 0,442 . Nilai $r_{x y} \neq 0$ menunjukan bahwa hipotesis menunjukan bahwa adanya signifikasi antara 
dua variabel yang berbanding lurus. Dapat dikatakan bahwa terdapat hubungan antara keterlibatan ayah dan pembentukan karakter pada remaja.

Dimensi yang memiliki nilai hubungan saling memperngaruhi paling besar adalah dimensi responsivity dan olah pikir dengan nilai korelasi 0,386. Dapat diartikan bahwa kasih sayang dan kehangatan ayah berpengaruh pada sisi kognitif sang anak. Selanjutnya, dimensi yang saling berhubungan dengan nilai koefisien korelasi yang sama adalah dimensi harshness dengan dimensi olah rasa yaitu 0,340 dengan demikian dapat diartikan bahwa sikap hangat, kasih sayang, dan sikap galak ayah dapat membantu membentuk rasa dan karsa yang baik dalam diri anak.

Sama seperti dimensi affective involvement dengan olah rasa, kedua dimensi ini juga memiliki nilai korelasi yang tinggi, yaitu sebesar 0,327 . Koefisien korelasi antara dimensi responsivity dengan olah hati sebesar 0,288. Koefisien korelasi antara dimensi responsivity dengan olah raga sebesar 0,285 . Koefisien korelasi antara dimensi harshness dengan olah hati sebesar 0,202. Koefisien korelasi antara dimensi harshness dengan olah pikir sebesar 0,251 . Koefisien korelasi antara dimensi behavioural engagement dengan olah pikir sebesar 0,282. Koefisien korelasi antara dimensi behavioural engagement dengan olah rasa sebesar 0,273.

Keterlibatan ayah dengan pembentukan karakter dalam diri responden tergolong sangat baik. Sikap hangat, supportif dan kasih sayang dari ayah ternyata berhubungan dengan pembentukan karakter anak dalam hal olah hati, olah pikir, olah raga, dan olah rasa. Setiap waktu yang ayah tuangkan dan kasih sayang yang dicurahkan, mampu membentuk kepribadian responden dalam 4 aspek pokok (olah hati, olah pikir, olah raga, dan olah rasa) dalam diri responden sebagai bentuk aplikasi dari karakter yang baik.

Selain sikap suportif, kasih sayang, dan kehangatan, hal lain yang sukses dilakukan ayah untuk membentuk karakter yang baik bagi anak-nya adalah penerapan dari sikap marah, sikap menghukum, dan pendekatan ayah. Tiga hal ini lekat hubungannya dalam membentuk karakter anak. Ketegasan dari ayah sangat diperlukan saat mendapati anaknya tidak jujur, tidak beribadah dengan baik, atau tidak mengerjakan PR (pekerjaan rumah). Rasa takut terhadap sosok ayah ini yang membuat anak takut untuk mengulangi kesalahannya.
Selain itu keterlibatan ayah dalam aktivitas juga membantu anak dalam membentuk karakter baiknya. Namun, terdapat satu aspek yang tidak selalu harus dipengaruhi oleh keikutsertaan ayah dalam aktivitas anak, yaitu pembentukan aspek olah raga dan karsa. Pada umumnya, setiap anak mampu memilih dan menerapkan sisi aspek ini tanpa bantuan ayah dan melihat dari prosentase analisis butir soal yang ada. Hal- hal yang menyangkut aspek ini memang bisa dilakukan sendiri oleh sang anak.

Keinginan dan kasih sayang dari ayah dalam kehidupan anak juga berhubungan dengan pembentukan karakter yang baik dalam diri seorang anak. Saat seorang ayah meyayangi dan menginginkan anaknya, ia akan turut serta dalam setiap fase yang dilewati oleh sang anak. Ayah dengan sukarela akan ikut memperhatikan dan memantau hal-hal baik, dan buruk bagi anaknya.

\section{KESIMPULAN}

Berdasarkan pengolahan deskriptif, analisis, dan pengolahan data penelitian dapat disimpulkan empat hal di bawah ini.

1. Terdapat hubungan yang signifikan dan searah antara keterlibatan ayah dengan pembentukan karakter pada remaja, dengan koefisien determinasi sebesar $19,5 \%$. Jadi, $19,5 \%$ variabel pembentukan karakter anak dipengaruhi oleh keterlibatan dari sang ayah.

2. Bentuk-bentuk keterlibatan dari ayah di antaranya adalah sikap suportif ayah, sikap hangat ayah, kasih sayang ayah, sikap marah dan menghukum, pendekatan diri ayah, keterlibatan ayah dalam aktivitas, dan keinginan ayah terhadap anak. Semua hal itu yang harus diaplikasikan ayah agar dapat membentuk karakter baik pada diri anak.

3. Dimensi yang memiliki nilai hubungan saling memperngaruhi paling besar adalah dimensi responsivity dan olah pikir, dengan nilai korelasi 0,386. Dapat diartikan bahwa kasih sayang dan kehangatan ayah berpengaruh pada sisi afektif anak. Selanjutnya, dimensi yang saling berhubungan dengan nilai koefisien korelasi yang sama adalah dimensi responsivity, harshness dengan dimensi olah rasa yaitu 0,340 . Dengan demikian dapat diartikan bahwa sikap hangat, kasih sayang, dan sikap galak ayah dapat membantu membentuk rasa dan karsa yang baik dalam diri anak. 
4. Karakter anak yang harus dikembangkan untuk menjadi pribadi yang berkualitas mencakup hal-hal yang berhubungan dengan aspek olah hati, olah pikir, olah raga dan kinestetik, dan yang terakhir olah rasa dan karsa.

\section{DAFTAR PUSTAKA}

Allen, S. Daly, K. 2002. The Effects of Father Involvement: An Updated Research Summary of the Evidence Inventory. Guelph: University of Guelph.

Erawati, M. 2008. Kajian metaanalisis; keterlibatan ayah dalam pengasuhan dan externalizing behavior pada anak. Jurnal disampaikan dalam diskusi peserta Program Doktoral Fakultas Psikologi UGM Rabu, 31 Desember 2008 di Yogyakarta.

Fox, G.L. \& Bruce, C. 2001. Conditional Fatherhood: Identity Theory and Parental Investment Theory as Alternative Sources of Explanation of Fathering. Journal Marriage and Family, 63, 394-403.

Kementrian Pendidikan Nasional. 2011. Panduan Pelaksanaan Pendidikan Karakter. Jakarta: Balai Pustaka.

Lamb, Michael. E. 2007. Father and Child Development: An Introductory Overview and Guide. Dalam M. Lamb (ed). The Role of the Father in Child Development Third Edition (1-18). USA: John Wiley \& Sons, Inc.

National Institute of Child Health and Human Development Early Child Care Research Network. 2000. Factors Associated With Father's Caregiving Activities and Sensitivity with Young Children. Journal of Family Pshycology. Vol. 14, No.2, pp 200219

Pusat Bahasa Departemen Pendidikan Nasional. 2005. Kamus Besar Bahasa Indonesia. Jakarta: Balai Pustaka

Pleck, Joseph H. 2005. Paternal Involvement: Levels, Sources and Consequences. Dalam M. Lamb (ed). The Role of Father in Child Development Third Edition (66103). USA: John Willey and Sons, Inc.

Sugiono. 2010. Metode Penelitian Pendidikan Pendekatan Kuantitatif, Kualitatif, dan $R$ dan D. Bandung: Alfabeta.

Lickona, T. 2001. Educating for Character: How Our School Can Teach Respect and Responsibility. New York: Bantam Books.

. 2012. Character Matters: Persoalan Karakter. terj. Juma Wadu Wamaungu \& Jean Antunes Rudolf Zien dan Editor Uyu Wahyuddin dan Suryani, Jakarta: Bumi Aksara.

. 2012. Educating for Character: Mendidik untk Membentuk Karakter. terj. Juma Wadu Wamaungu dan Editor Uyu Wahyuddin dan Suryani, Jakarta: Bumi Aksara.

Vera, I. 2008. Tanya Jawab Seputar Perilaku Anak. Jakarta: Buana Ilmu Populer.

http://internasional.kompas.com.indonesia.negar a.korup. Diakses tanggal 18 November 2014.

https://kbogorbonline.wordpress.com/wartainternasional/. Diakses tanggal 18 November 2014.

https://merdeka-online.com/data-sensusBKKBN/. Diakses anggal 18 November 2014.

https://Lodaya-web.net/tawuran-pelajarsemakin-tinggi-kasusnya/.Diakses tanggal 18 November 2014.

http://www.bkkbn.go.id./ Data Ketahanan Keluarga (Online). Diakses tanggal 18 November 2014.

http://www.bps.go.id./ Data Kenakalan Remaja (Online). Diakses tanggal 18 November 2014. 